\title{
Comparison of Sous-vide methods and traditional hydrothermal treatment on GLS content in Brassica vegetables
}

\author{
Adam Florkiewicz $^{1}$ - Ewa Ciska ${ }^{2} \cdot$ Agnieszka Filipiak-Florkiewicz $^{3} \cdot$ Kinga Topolska $^{3}$
}

Received: 11 November 2016 / Revised: 27 January 2017 / Accepted: 19 February 2017 / Published online: 22 March 2017

(C) The Author(s) 2017. This article is an open access publication

\begin{abstract}
Brassica vegetables are a source of many biologically active compounds, including glucosinolates (GLS). At present, GLS attract a special attention because of their healthy properties. Four Brassica vegetables: cauliflower, Romanesco-type cauliflower, Brussels sprouts, and broccoli were examined. Analyses of GLS were done in raw, sous-vide cooked, traditionally cooked, and steamed vegetables as well as in samples stored for 5 days at $2 \pm 1{ }^{\circ} \mathrm{C}$. In the examined vegetables, 9 GLS were identified. The content of vitamin $\mathrm{C}$ was also determined. Moreover, microbiological analyses were performed. Among the investigated vegetables, the highest content of GLS was observed in the steamed samples. The traditional cooking of broccoli and Romanesco-type cauliflower causes a significant decrease of GLS as compared to the raw materials. The same explicit tendency was also observed in the case of cooking by the sous-vide method of Romanescotype cauliflower and Brussels sprouts. Brussels sprouts, cooked by the sous-vide method, contained almost $40 \%$ less GLS than those cooked in water. Storage of the treated vegetables at $2 \pm 1{ }^{\circ} \mathrm{C}$ led to a further reduction of the GLS level. It must be emphasized that the highest losses were observed in broccoli after sous-vide cooking (over 30\%).
\end{abstract}

Adam Florkiewicz

a.florkiewicz@ur.krakow.pl

1 Department of Food Analysis and Quality Assessment, Faculty of Food Technology, University of Agriculture in Krakow, 122 Balicka St., 30-149 Krakow, Poland

2 Institute of Animal Reproduction and Food Research of the Polish Academy of Sciences, Tuwima 10, 10-748 Olsztyn, Poland

3 Department of Nutrition Technology and Consumption, Faculty of Food Technology, University of Agriculture in Krakow, 122 Balicka St., 30-149 Krakow, Poland
Our results indicate that sous-vide method can be an advantageous technique of processing broccoli destined only for direct consumption.

Keywords Sous-vide method · Cooking · Steaming · Glucosinolates $\cdot$ Brussels sprouts $\cdot$ Cauliflower

\section{Introduction}

GLS (GLS) are sulfur- and nitrogen-containing plant secondary metabolites common in Brassica vegetables [1]. The characteristic flavour and odour of these vegetables are the result of the presence of GLS. GLS and their breakdown products are of particular interest in food research because of their anticarcinogenic properties [2]. A number of epidemiological studies have identified an inverse association between the consumption of Brassica vegetables and the risk of colon and rectal cancer [3]. The GLS are not biologically active themselves, but only their enzymatic derivatives are [4]. The products of GLS breakdown, particularly the aromatic and indole products, have been shown to act as anticarcinogens by inhibition of the phase I enzymes and induction of the phase II enzymes that affect the xenobiotic transformations. Similar effects are also described for some degradation products of the aliphatic GLS [5]. This is why nutritional recommendations suggest an increase in the total consumption of Brassica vegetables, such as cabbage, Brussels sprouts, cauliflower, broccoli, etc.

In the Brassicaceae family, the plant's genetic background is the major factor determining GLS concentration and composition, although environmental conditions and physiological factors also influence GLS expression and accumulation [3]. On the other hand, many steps in the food production chain, such as processing and preparation 
of vegetables as well as the preservation method, may have an impact on the levels of GLS $[4,6]$. Most GLS are relatively stable at high temperatures, but are easily enzymatically hydrolyzed by the enzyme-myrosinase. This enzyme is present in the Brassica vegetables' tissues and is released into the plant cells due to damage, for example, during the technological processes [7]. Several studies [8-11] are concerned on the methods of GLS extracting from raw plant materials to obtain the highest possible amount of these compounds in the sample. The inactivation of myrosinase is one of the crucial issues. Meanwhile, pretreatmentbeing a necessary step in technological processing of vegetables-could cause mechanical damage (physical injury) and thus led to the activation of myrosinase. According to Oerlemans and Barrett [2], also during thermal processing of Brassica vegetables, the GLS levels can be reduced because of several mechanisms: enzymatic breakdown, thermal breakdown, and leaching into the heating medium. Cooking at high temperatures, denatures myrosinase in the vegetable material, resulting in a lower conversion of GLS to isothiocyanates when chewed. GLS of consumed vegetables are degraded to isothiocyanates (ITC) by myrosinase of the gut bacteria [12]. Angelino et al. [13] suggest that plant myrosinase is essential for an effective dose of ITC to be formed and absorbed, supporting the traditional idea that cooked Brassica are less likely to provide health benefits than uncooked vegetables. In the study performed by Vermeulen et al. [14], plasma sulforaphane and metabolites in those eating cooked broccoli were one-tenth that of those eating raw broccoli.

According to Cieślik et al. [15], the traditional cooking (raw or frozen) of Brassica vegetables resulted in a significant reduction of GLS. The sous-vide (SV) cooking method is one of the many variants of the cook and chill catering technology. It is nowadays employed to process convenience foods, including ready meals. It consists in cooking of highly nutritious raw materials (e.g., vegetables) at product-specific temperatures and time in vacuum pouches, followed by rapid chilling and low-temperature storage $\left(0-3{ }^{\circ} \mathrm{C}\right)[16]$. This method improves sensory quality (i.e., texture, tenderness, and flavour) as well as preserves the nutritional status more than conventional cooking. In the literature, little is known about the influence of vegetable cooking under low temperature and after vacuum packaging on the level of GLS in the final products.

Taking into consideration growing popularity of SV method, the knowledge of its effect on biological important dietary components is truly needed but not only from methodological but also from consumer point of view (the real GLS amount consumed with the vegetables after all treatments-ready to eat products). For that reason, the aim was to compare the effect of sous-vide cooking vs traditional cooking or steaming, on the GLS content in selected
Brassica vegetables. To make this research more distinctive from other of this type and having regard to important role of vitamin $\mathrm{C}$ in activation of myrosinase, the level of this compounds in raw materials was also determined. Moreover, to ensure consumer safety, microbiological quality of processed vegetables was assessed.

\section{Materials and methods}

\section{Material}

Four common Brassica vegetables: cauliflowers (Brassica oleracea var. botrytis),- white rose and Romanesco-type cauliflower-green rose, Brussels sprouts (Brassica oleracea var. gemmifera), and broccoli (Brassica oleracea var. botrytis italica) were investigated. The vegetables were bought in a local supermarket (Krakow, Poland) in 2014. The batch of each vegetable ( $5 \mathrm{~kg}$ green mass, in triplicate) was cut vertically (into four or eight pieces, depending on their size), and then divided into four sub-samples, which were subsequently used as raw $(n=3)$, cooked by the sous-vide method $(n=3)$, "traditionally"-in water (at 500:1500 ratio of vegetables to water, $\mathrm{m} / \mathrm{v}$ ), cooked $(n=3)$, and steamed $(n=3)$. Raw vegetables were washed under running water, dried on filter paper, divided into florets (excluding Brussels sprouts), and then frozen at $-22 \pm 1{ }^{\circ} \mathrm{C}$. After freezing, this sub-sample was immediately freeze-dried using a Christ Alpha 1-4 apparatus (Christ, Germany), and ground in Tecator Knifetec 1095 Sample Mill (Tecator, Sweden), until uniform powder was obtained. The sous-vide cooking was performed using a sous-vide system-model 225,448 (Hendi, Germany), at $90{ }^{\circ} \mathrm{C}$ for $45 \mathrm{~min}$ (cauliflowers and broccoli) or $50 \mathrm{~min}$ (Brussels sprouts). This process was preceded by vacuum packaging in VBN-4 (RM Gastro, Czech Republic). The traditional cooking of vegetables was carried out in unsalted water for 10 (cauliflowers and broccoli) or $15 \mathrm{~min}$ (Brussels sprouts), in a stainless steel pot, on the induction stove (Hendi, Germany). Sample steaming was performed using Combi-Steam Oven model 225,547 (Hendi, Germany) at $100{ }^{\circ} \mathrm{C}$ for $7 \mathrm{~min}$. On the basis of the results of preliminary studies, one timepoint for each treatment was chosen. The main criterium was organoleptic characteristic of the final product (consumer acceptance).

After each thermal treatment, the vegetables were immediately chilled in RedFox SHS-511 shock cooling chamber (RM Gastro, Czech Republic) and stored at a controlled temperature of $2 \pm 1{ }^{\circ} \mathrm{C}$ for 5 days. The preparation of samples after thermal treatment and storage for the analyses was performed by the same procedure as used for raw vegetables. 


\section{Chemical analysis}

The content of dry matter was determined by gravimetric methods according to Polish standard [17] and expressed in g per $100 \mathrm{~g}$. The analysis of vitamin C (L-ascorbic acid) content was performed by the colorimetric method, according to Megazyme assay procedure K-ASCO 01/14. Approximately $10 \mathrm{~g}$ of vegetables were homogenized with $10 \mathrm{~mL}$ of $1 \mathrm{M}$ potassium phosphate buffer ( $\mathrm{pH} \mathrm{3.5)}$ for $1 \mathrm{~min}$. Then, the $\mathrm{pH}$ was adjusted to 3.5-4.0 with $2 \mathrm{M} \mathrm{KOH}$ and the mixture was quantitatively transferred to a $500 \mathrm{~mL}$ volumetric flask, filled in using distilled water, mixed, and filtered. The calculation of L-ascorbic acid content was done by the use of Megazyme Mega-Calc ${ }^{\mathrm{TM}}$, downloaded from the Megazyme website (http://www.megazyme.com), and the results were expressed in mg per $100 \mathrm{~g}$ wet weight. On the basis of the differences between initial (before process) and final (after process) mass of vegetables, process efficiency (\%) was calculated.

Analyses of GLS (GLS) were done in raw, sous-vide cooked, traditionally cooked (in water), and steamed vegetables as well as in the samples stored for 5 days at a controlled temperature of $2 \pm 1{ }^{\circ} \mathrm{C}$. GLS were extracted from the research materials according to the method reported in the Official Journal of European Communities [18]. Briefly, duplicate $200 \mathrm{mg}$ samples of freeze-dried material were extracted thrice with cooking $70 \%$ methanol. Since all the examined vegetables lacked glucotropaeolin, a known amount was added to each sample just before the first extraction, as an internal standard for the HPLC analysis. The isolation, desulphatation, and chromatographic analysis of GLS was carried out according to the modified method of Heaney et al. [19]. Desulpho-GLS were separated on the HPLC system with an auto injector, Spherisorb ODS-2 3 Micron column $(150 \mathrm{~m} \times 4.6 \mathrm{~mm})$, and $1.2 \mathrm{ml} /$ min flow rate at $32{ }^{\circ} \mathrm{C}$ by eluting with a gradient of water (A) and 20\% acetonitrile (B) as follows: isocratically $1 \%$ B for $1 \mathrm{~min}$, gradient to $99 \%$ B for $30 \mathrm{~min}$, isocratically $99 \%$ $\mathrm{B}$ for $6 \mathrm{~min}$, linear gradient to $1 \% \mathrm{~B}$ for $5 \mathrm{~min}$, and $1 \% \mathrm{~B}$ for $8 \mathrm{~min}$. GLS were detected at $k=229 \mathrm{~nm}$. The content of GLS was quantified using the internal standard as well as relevant relative response factors [18], and expressed in $\mu \mathrm{mol}$ per $100 \mathrm{~g}$ of fresh weight.

\section{Microbiological analysis}

The microbiological status of cooked (all methods) vegetables as well as the samples after storage was analyzed immediately after the process. The fresh vegetables were analyzed in the day of purchase.

To determine the total count of microorganisms, the horizontal method was used, according to PN-EN ISO 4833-1:2013-12E [20]. The enumeration of coliforms was performed on the basis of PN-ISO 4832/2007 [21], Listeria monocytogenes according to PN-EN ISO 112902/2000 [22] and anaerobic bacteria according to PN-ISO 15213:2005P [23].

\section{Statistical analysis}

All technological treatments and analysis were done in triplicate. The results were expressed as mean values $\pm \mathrm{SD}$ (standard deviation). The data were subjected to two-factorial $(4 \times 3)$ analysis of variance, including four species of Brassica vegetables and three processing methods. The differences between the means were evaluated using the posthoc NIR Fisher test, with the significance level established at $\alpha<0.05$. Statistica 10.1 software package (StatSoft Inc., USA) was used for statistical analysis.

\section{Results and discussion}

\section{Dry matter content and microbiological quality of Brassica vegetables: raw and after different cooking treatments}

It was shown that the dry matter levels in raw cauliflower, broccoli, Romanesco-type cauliflower, and Brussels sprouts were $8.42,12.81,13.95$, and $15.05 \mathrm{~g} / 100 \mathrm{~g}$, respectively (Table 1). Similar results for cauliflower $(7.8 \mathrm{~g} / 100 \mathrm{~g})$ and Brussels sprouts $(14.9 \mathrm{~g} / 100 \mathrm{~g})$ as well as lower for Romanesco-type cauliflower $(9.6 \mathrm{~g} / 100 \mathrm{~g})$ and broccoli $(9.6 \mathrm{~g} / 100 \mathrm{~g})$ were obtained by Cieślik et al. [15]. A higher dry matter content in cauliflower was determined by Ahmed and Ali [24]. In turn, Gębczyński and Lisiewska [25] reported $10.34 \mathrm{~g} / 100 \mathrm{~g}$ of the dry matter in broccoli. These differences may be due either to the species or the varietal diversification or different cultivation conditions. The traditional cooking of all the examined vegetables led to a statistically significant decrease in the dry matter amount. Such observations concerning Brassica vegetables were made also by other authors $[15,24,26]$. Steamed vegetables had the highest content of dry matter. The increase of this parameter in Brussels sprouts var. Ajax, as compared to raw vegetable, was shown by Podsędek et al. [27]. The results regarding the dry matter levels in raw vegetables as well as these subjected to thermal processing are in line with the values relating to the process efficiency. The highest efficiency was obtained for the traditional cooking, indicating that the increase in weight of the cooked vegetables was due to water absorption, dilution of their constituents, and finally the reduction of dry matter content in the finished product. The minimal (from 0.6 to $6.7 \%$ ) real losses of dry matter (having regard to the process efficiency) in vegetables subjected to cooking by the sous-vide method 
Table 1 Content of dry matter and the efficiency of vegetable thermal processing

\begin{tabular}{llll}
\hline Vegetable & Sample treatment & Dry matter $(\mathrm{g} / 100 \mathrm{~g})$ & $\begin{array}{l}\text { Efficiency } \\
\text { of process } \\
(\%)\end{array}$ \\
\hline Cauliflower & Raw & $8.42 \mathrm{~b} \pm 0.03$ & - \\
& Sous vide & $8.22 \mathrm{~b} \pm 0.03$ & 98.0 \\
& Cooking & $7.80 \mathrm{a} \pm 0.34$ & 101.0 \\
& Steaming & $8.67 \mathrm{~b} \pm 0.43$ & 95.0 \\
Broccoli & Raw & $12.81 \mathrm{~b} \pm 0.27$ & - \\
& Sous vide & $12.85 \mathrm{~b} \pm 0.51$ & 98.0 \\
& Cooking & $10.89 \mathrm{a} \pm 0.26$ & 102.7 \\
& Steaming & $14.25 \mathrm{c} \pm 0.39$ & 89.7 \\
Romanesco-type cauliflower & Raw & $13.95 \mathrm{~b} \pm 0.59$ & - \\
& Sous vide & $14.01 \mathrm{c} \pm 0.39$ & 99.0 \\
& Cooking & $12.63 \mathrm{a} \pm 0.15$ & 104.3 \\
& Steaming & $14.89 \mathrm{c} \pm 0.61$ & 91.8 \\
Brussels sprouts & Raw & $15.05 \mathrm{c} \pm 0.37$ & - \\
& Sous vide & $14.25 \mathrm{~b} \pm 0.09$ & 98.5 \\
& Cooking & $13.40 \mathrm{a} \pm 0.40$ & 102.3 \\
& Steaming & $15.40 \mathrm{c} \pm 0.74$ & 94.0 \\
\hline
\end{tabular}

The values of dry matter content are expressed as mean \pm SD

The values marked with the same letters not differ significantly at $p>0.05$ were observed, and the reason could be primarily the previous vacuum packaging (thus preventing direct contact of raw material with water), and also a lower temperature of the process as compared to the traditional cooking.

The raw materials were characterized by total microbial counts from $4.4 \times 10^{3} \mathrm{cfu} / \mathrm{g}$ (cauliflower-white rose) to $8.9 \times 10^{6} \mathrm{cfu} / \mathrm{g}$ (broccoli). In all fresh vegetables, Listeria monocytogenes was present $\left(6.7 \times 10^{1}-9.0 \times 10^{2}\right)$. Moreover, in the case of Romanesco-type cauliflower $\left(3.0 \times 10^{3}\right)$ as well as broccoli $\left(8.5 \times 10^{2}\right)$, coliforms were detected. The analysis of microbiological quality did not show the presence of Listeria monocytogenes, anaerobic bacteria, and coliforms, neither immediately after the process, nor after 5 days of storage at $2 \pm 1^{\circ} \mathrm{C}$. The total microbial count in steamed vegetables varied from $6.0 \times 10^{1}$ to $8.5 \times 10^{1} \mathrm{cfu} / \mathrm{g}$, and in traditionally cooked vegetables-from $2.5 \times 10^{1}$ to $1.6 \times 10^{2} \mathrm{cfu} / \mathrm{g}$, whereas in the samples subjected to a sousvide cooking, it ranged between $2.4 \times 10^{2}$ and $9.8 \times 10^{3}$ $\mathrm{cfu} / \mathrm{g}$. After 5 days of storage, an enhancement of the total microbial count was observed, with the highest value obtained for cauliflower $\left(6.4 \times 10^{4} \mathrm{cfu} / \mathrm{g}\right)$.

\section{The GLS changes after different cookings of vegetables as compared to raw materials}

Nine GLS (GLS), including six aliphatic and three indole, were identified by the HPLC method in the examined Brassica vegetables (Table 2). In addition, the total GLS levels were calculated.

\section{GLS content in raw vegetables}

Among the evaluated vegetables, Brussels sprouts were characterized by the highest content of GLS (215.26 $\mu \mathrm{mol} / 100 \mathrm{~g}$ wet weight). The higher values were obtained by Ciska et al. [28] and Carlson et al. [29], whereas lower-by Song and Thornalley [12]. It was also shown that sinigrin, glucoiberin, and glucobrassicin dominated in this vegetable. Similar tendencies were reported by Ciska et al. [5] as well as Cieślik et al. [15].

Significantly less GLS were determined in Romanescotype cauliflower $(133.4 \mu \mathrm{mol} / 100 \mathrm{~g}$ wet weight) and broccoli (119.24 $\mu \mathrm{mol} / 100 \mathrm{~g}$ wet weight), with the highest amount obtained for glucoraphanin. Meanwhile, sinigrin was not present in Romanesco-type cauliflower (Table 2). These results were in line with those obtained by Cieślik et al. [15]. Brown et al. [30] reported that the glucoraphanin was dominant GLS in ten genotypes of broccoli grown over different environments. Similar data were obtained by Song and Thornalley [12].

The lowest GLS content was found in white rose cauliflower $(62.25 \mu \mathrm{mol} / 100 \mathrm{~g}$ wet weight), as presented in Table 2. Delonga et al. [31] obtained higher amounts of GLS sum, whilst lower values were reported by Mithen et al. [32] as well as Song and Thornalley [12].

GLS are hydrolyzed by the enzyme myrosinase (thioglucohydrolase; E.C.3.2.1.147) to the various compounds (isothiocyanates, nitriles, thiocyanates, epithionitriles, and oxazolidine-2-thiones) [33]. Mithen et al. [32] stated that 
if the breakdown happens as the result of plant-derived myrosinase action, GLS are rapidly hydrolyzed in the proximal part of the intestine. If myrosinase is inactivated (for example, by the thermal treatment) before vegetable consumption, ionized form of GLS enables them to reach distal part of the intestine (when they are metabolized by bacterial enzymes). According to Mithen et al. [32], myrosinase is located in the cytoplasm of specialist myrosin cells scattered throughout the plant tissue and may also be located in the cytoplasm of other cells. Upon mechanical injury of the tissue (e.g., chewing or cutting), the enzyme comes in contact with its substrate and hydrolyzes it [34].

The extent of hydrolysis of GLS and the nature as well as the composition of the breakdown products formed are known to be influenced by various characteristics of the hydrolysis medium. Intrinsic factors, such as coexisting myrosinase and its cofactors ascorbic acid, epithiospecifier protein (ESP), or ferrous ions and extrinsic factors, such as $\mathrm{pH}$ and temperature, can affect the hydrolysis of GLS [35].

Among the examined vegetables, the highest content of ascorbic acid was found in Brussels sprouts, and the lowest-in Romanesco-type cauliflower (Table 2). The high level of vitamin C $(98.3 \mathrm{mg} / 100 \mathrm{~g})$ in raw Brussels sprouts could contribute to enhanced myrosinase activity and GLS breakdown. There was $215.26 \mu \mathrm{mol} \mathrm{GLS} / 100 \mathrm{~g}$ wet weight in fresh vegetables and up to $330.91 \mu \mathrm{mol} / 100 \mathrm{~g}$ wet weight in steamed samples (thermal inactivation of myrosinase)—Table 3 .

There are evidences that the content of GLS in fresh vegetables can be underestimated due to the methodological limitations [8, 28]. For this reason, it is difficult to evaluate the real initial value of GLS when regarding the effect of different technological processes on their amount. For example, Verkerk and Dekker [36] proposed the subjection of plant material to short-term thermal processing (cooking in water or microwaving) before GLS determination. In their opinion, GLS are better extracted from cooked vegetables than from raw materials. Vallejo et al. [37] showed that steaming of broccoli for 3.5 min causes a minimal reduction of GLS, confirming the efficacy of this method in the inactivation of endogenous myrosinase.

Rungapamestry et al. [35] demonstrated that steaming for $420 \mathrm{~s}$ leads to over a $90 \%$ reduction of this enzyme. Our results confirmed that steamed vegetables were characterized by the highest extractable GLS content. It is to emphasize that the method applied to vegetable processing was using the apparatus with forced convection, enabling additional enhancement of heat transfer coefficient, and in consequence possibly fast increase in the temperature inside the product.

Our study showed that steaming of vegetables resulted in a significant enhancement of GLS content as compared to fresh vegetables. Particular importance attaches the level 


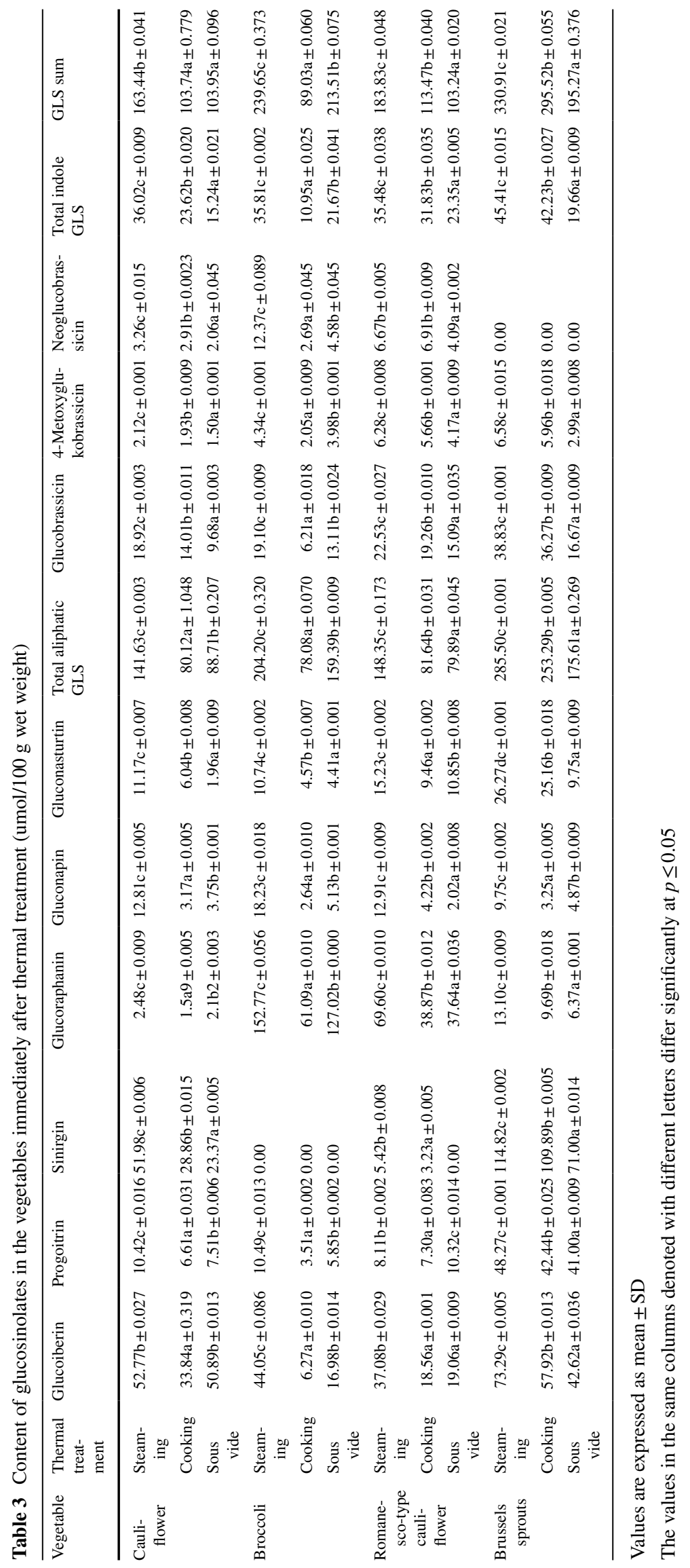


of GLS, mainly glucoiberin and sinigrin, in cauliflower. This vegetable, subjected to steaming, contained over 2.5fold higher amount of GLS than raw cauliflower. Twice as much GLS, in particular aliphatic, were determined also in the case of steamed broccoli. The subjection of Brussels sprouts to this process led to 1.53-fold increase in GLS. According to the study of Ciska et al. [28], the initial value (being the sum of GLS in cooked Brussel sprouts and in the water left after the process) was 1.37-fold higher, compared with fresh vegetable. Miglio et al. [38] showed higher concentration of GLS in steamed broccoli $(93.4 \mu \mathrm{mol} / \mathrm{g} \mathrm{d}$.m.), in comparison with raw $(71.4 \mu \mathrm{mol} / \mathrm{g} \mathrm{d}$.m. $)$ and traditionally cooked vegetable $(29.3 \mu \mathrm{mol} / \mathrm{g}$ d.m. $)$.

In light of the obtained results, as well as literature data, when discussing the effect of other technological processes, the level of GLS obtained for steamed vegetables was taken as the initial value of their content.

In our opinion, it is all the more justified that in most vegetables, this level was stable also during storage at $2 \pm 1{ }^{\circ} \mathrm{C}$ of ready to eat products. After 5 days of storage, steamed cauliflower and broccoli contained over $95 \%$ of GLS value determined immediately after the process (Table 4). Although in the case of Romanesco-type cauliflower as well as Brussels sprouts, this amount was lower; it was, however, over $80 \%$ initial value.

\section{Comparison of different cooking methods (traditional cooking, sous vide, and steaming) on GLS content}

Brassica vegetables, besides beneficial health effects, can exert toxic and goitrogenic action. Nonetheless, as most of vegetables that are abundant in 2-hydroxyalkenyl GLS are cooked before consumption, the goitrogenic action should not have been counted [39]. The study performed by Verkerk [40] showed the reduction (40-70\%) in GLS content during cooking, which was mainly caused by the transition of these compounds to water. As a result, it was recognized that microwave cooking (in view of small amount of necessary water) would be a better method of vegetable processing. Meanwhile, this method leads not only to high losses of vitamin C, but also over a 70\% reduction of GLS [cit. from 2].

In our opinion, the sous-vide method can be a considerable alternative of cooking. This method-because of barrier heating (earlier vacuum packaging) - makes impossible the direct contact between raw material and water environment. From the other side, it is characterized by a lower range of the used temperatures.

Sous-vide cooking of broccoli led to higher GLS content in comparison with traditionally cooked vegetables as well as similar to steamed broccoli (Table 3). Among the analyzed compounds, glucoraphanin, glucoiberin, progoitrin, and glukonapin were in higher amounts (almost twofold) in broccoli prepared by the sous-vide method, comparing to vegetable cooked traditionally in the water. As regards indole GLS, it was twice more glucobrassicin than 4-metoxyglucobrassicin. Differences in thermal the breakdown of GLS can be the result of the presence of specific plant components, which negatively influence the GLS stability. The higher content of GLS in plant tissues, the higher it will be their susceptibility to breakdown [4]. It was shown that the total content of GLS was similar in cooked and SV-treated cauliflower, with higher amount of indole GLS (especially glucobrassicin) in traditionally (in water) cooked vegetable and lower level of aliphatic GLS (mainly glucoiberin) in relation to cauliflower prepared by the sous-vide method.

Cooking of Brussels sprouts and Romanesco-type cauliflower by the sous-vide method resulted in much higher losses of GLS, both indole and aliphatic, in comparison with the traditional cooking. It is to emphasize that the use of this technique of processing was particularly disadvantageous and reduced the total content of GLS, also in relation to raw vegetable. Simultaneously, a slight increase was observed in the amount of indole GLS (glucobrassicin and 4-metoxyglucobrassicin) in Romanescotype cauliflower was observed. Kapusta-Duch et al. [4] reported that cooking causes a significant decrease in the content of GLS, comparing it with raw vegetables. These authors observed that indole GLS were more susceptible to processing, and their losses gained over 90\% (mainly glucobrassicin). Added to that is the fact that sinigrin was not identified in sous-vide cooked Romanesco-type cauliflower, whereas this compound was present both in traditionally cooked and steamed vegetables. Myrosinase inactivation in Brassica vegetables, as the effect of cooking, can reduce GLS breakdown, which results in GLS consumption (instead the products of their breakdown). It is known that GLS can be hydrolyzed not only by myrosinase, but they are also degraded by temperature as well as reduced to isothiocyanates by gut microflora [41]. It is to emphasize that the temperatures during processing by SV method are relatively low. Thus, the thermal degradation of GLS (observed in our study) was probably lower than during traditional cooking. Isothiocyanates are responsible for the reduction in the risk of many cancers [6]. Anticancer properties of these compounds arise from inhibition of phase I enzymes (the role in carcinogen bioactivation) and induction of phase II enzymes [41]. According to Sarvan et al. [41], an optimal technological process should allow to preserve GLS in the unchanged form.

Brussels sprouts, cooked by the sous-vide method, contained almost $40 \%$ less GLS than cooked in water. The exception was gluconapin, with a $50 \%$ higher content in the samples after sous-vide cooking. As Sarvan et al. [34] 


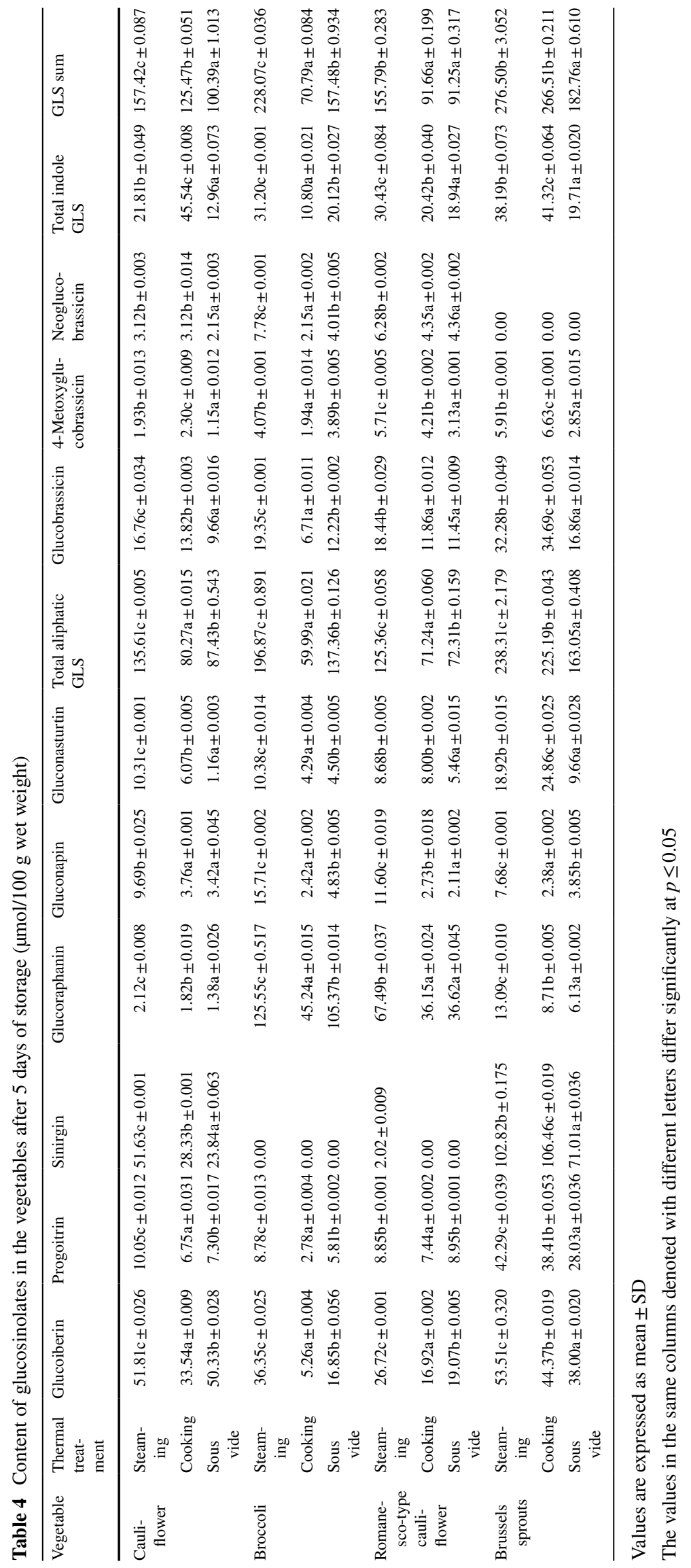


reported, GLS in Brussels sprouts are less stable in the vegetable than leached into cooking water.

Looking at the changes in GLS content under the influence of sous-vide and traditional cooking, compared to the initial value (that was GLS in steamed vegetable taken), it was shown that sous-vide cooking, of both cauliflower and Brussels sprouts, led to higher losses than cooking in water (Fig. 1). The opposite tendency (both in indole and aliphatic GLS) was observed only in the case of broccoli. The possible reason could be different water activity, being one of the factors influencing myrosinase activity. The differences among species of Brassica vegetables in susceptibility for thermal and enzymatic degradation of GLS could be another important issue. The obtained results indicate that cooking at a lower temperature after previous vacuum packaging can be advantageous form of broccoli processing, among studied vegetables. Given the results concerned on GLS content in stored vegetables, however, it should be noted that losses, in comparison with values gained immediately after the process, were the highest (among all vegetables) in sous-vide cooked broccoli and reached over 30\% (Tables 3, 4). Meanwhile, the losses observed in other vegetables were between 4 and 20\%. From these results, it is considered that the use of the sous-vide method, in the context of preserving as high a content of GLS as possible, is proper only in the case of broccoli destined for direct consumption (cook and serve system).

The storage at $2 \pm 1{ }^{\circ} \mathrm{C}$ of sous-vide-cooked broccoli caused a significant decrease of the glucoraphanin content (Table 4). After 5 days of storage, steamed cauliflower contained markedly less gluconapin. Meanwhile, in the case of Romanesco-type cauliflower and Brussels sprouts, storage was particularly disadvantageous for vegetables prepared by the sous-vide method. They were characterized by significantly less amount of progoitrin, gluconasturcin (Romanesco-type cauliflower), and also gluconapin (Brussels sprouts). 5-day storage of broccoli and Brussels sprouts subjected to traditional cooking led to the losses, mainly in aliphatic GLS, whereas cauliflowers-indole GLS.

Further studies are needed to assess not only the effect of sous-vide method on the level of GLS, but also their breakdown products. It is important because of the anticancer properties of these compounds.

\section{Conclusions}

Cooking of vegetables by the sous-vide method is used as the alternative to traditional techniques of dish preparation. We found that the losses of dry matter (having regard to process efficiency) were slight in the case of vegetables cooked by the sous-vide method, whereas the traditional cooking of all the examined vegetables led to a statistically significant decrease in the dry matter content as compared to the raw material.

The usage of a lower temperature during cooking by the sous-vide method did not affect the quality and microbiological safety of the vegetables.

In the examined vegetables, nine GLS were identified. According to literature data, the estimation of GLS content in raw vegetables is quite difficult (underestimated). Our results showed that a higher (in comparison to raw vegetable) level of GLS was found in steamed vegetables. Thus, the content of these compounds in steamed vegetables was taken as an initial amount of GLS.
Fig. 1 Percentage changes in GLS content in vegetables subjected to a sous vide or traditional cooking, as compared to the initial value (GLS content in steamed vegetables regarded as $100 \%$ )

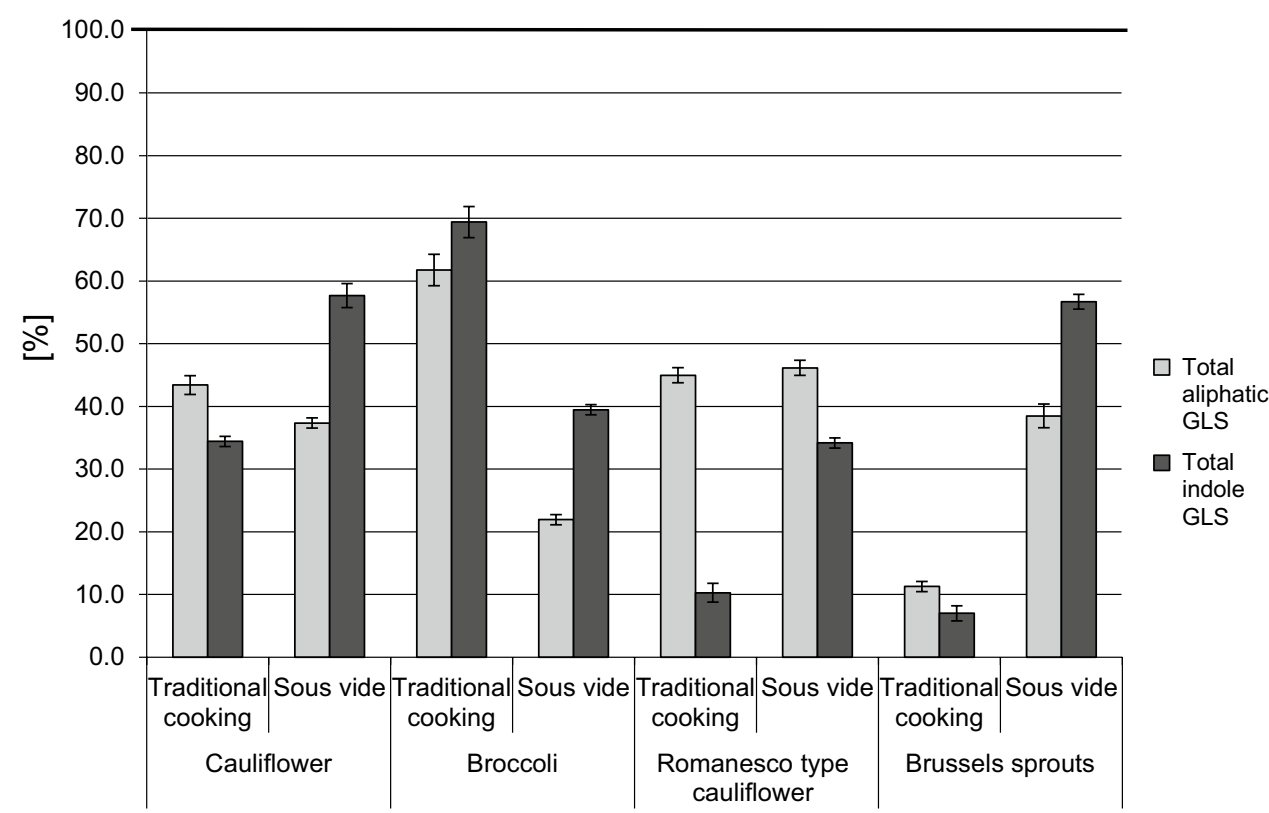


Glucoraphanin, glucoiberin, progoitrin and gluconapin, glucobrassicin as well as 4-metoxyglucobrassicin were in higher amounts in broccoli prepared by the sous-vide method, compared to the vegetables cooked traditionally in water.

Cooking of Brussels sprouts and Romanesco-type cauliflower by the sous-vide method resulted in much higher losses of GLS, in comparison with the traditional cooking. It is to emphasize that the use of this technique of processing was particularly disadvantageous and led to a decrease in the total content of GLS, also as compared to the raw vegetable.

Our results may indicate that SV cooking can be an advantageous processing method of broccoli destined for direct consumption.

Acknowledgements This study was supported by the Ministry of Science and Higher Education of Poland (subsidy for the purpose of maintaining research potential).

Conflict of interest The authors declare that they have no conflict of interest.

Compliance with ethics requirements This article does not contain any studies with human or animal subjects.

Open Access This article is distributed under the terms of the Creative Commons Attribution 4.0 International License (http:// creativecommons.org/licenses/by/4.0/), which permits unrestricted use, distribution, and reproduction in any medium, provided you give appropriate credit to the original author(s) and the source, provide a link to the Creative Commons license, and indicate if changes were made.

\section{References}

1. Redovniković IR, Glivotić T, Delonga K, Vorkapić-Furač J (2008) GLS and their potential role in plant. Period Biol 110:297-309

2. Oerlemans K, Barrett DM (2006) Carme Bosch Suades, Ruud Verkerk, Matthijs DekkerThermal degradation of GLS in red cabbage. Food Chem 95:19-29

3. Verkerk R, Schreiner M, Krumbein A, Ciska E, Holst B, Rowland I, de Schrijver R, Hansen M, Gerhuser C, Mithen R, Dekker M (2009) GLS in Brassica vegetables: the influence of the food supply chain on intake, bioavailability and human health. Mol Nutr Food Res 53:S219-S265

4. Kapusta-Duch J, Kusznierewicz B, Leszczyńska T, Borczak B (2016) Effect of cooking on the contents of GLS and their degradation products in selected Brassica vegetables. J Funct Foods 23:412-422

5. Ciska E, Martyniak-Przybyszewska B, Kozlowska H (2000) Content of GLS in cruciferous vegetables grown at the same site for two years under different climatic conditions. J Agric Food Chem 48(7)286:2-2867

6. Oliviero T, Verkerk R, Dekker M (2012) Effect of water content and temperature on GLS degradation kinetics in broccoli (Brassica oleracea var. italica). Food Chem 132(4):2037-2045
7. Szwejda-Grzybowska J (2011) Antykancerogenne składniki warzyw kapustnych i ich znaczenie w profilaktyce chorób nowotworowych. Brom Chem Toksykol XLIV(4):1039-1046 (in Polish)

8. Fahey JW, Zhang Y, Talalay P (1997) Broccoli sprouts: an exceptionally rich source of inducers of enzymes that protect against chemical carcinogens. Proc Natl Acad Sci USA 94:10367-10372

9. Fahey JW, Holtzclaw WD, Wehage SL, Wade KL, Stephenson KK, Talalay P (2015) Sulforaphane Bioavailability from Glucoraphanin-Rich Broccoli: Control by Active Endogenous Myrosinase. PLOS One 2:1-13, doi:10.1371/journal. pone.0140963

10. Zhou J, Hu J, Qiu A (2005) Separation and purification of the main glucosinolate from rapeseeds. Se Pu 23(4):411-414

11. Devi JR, Thangam EB (2010) Extraction and Separation of Glucosinolates from Brassica Oleraceae var Rubra. Adv Biol Res 4(6):309-313,

12. Song L, Thornalley PJ (2007) Effect of storage, processing and cooking on GLS content of Brassica vegetables. Food Chem Toxicol 45:216-224

13. Angelino D, Dosz EB, Sun J, Hoeflinger JL, van Tassell ML, Chen P, Harnly JM, Miller MJ, Jeffery EH (2015) Myrosinasedependent and -independent formation and control of isothiocyanate products of GLS hydrolysis. Fron. Plant Sci 6:831. doi:10.3389/fpls.2015.00831

14. Vermeulen M, Klopping-Ketelaars IW, van den Berg R, Vaes WH (2008) Bioavailability and kinetics of sulforaphane in humans after consumption of cooked versus raw broccoli. J Agric Food Chem 56(22):10505-10509

15. Cieślik E, Leszczyńska T, Filipiak-Florkiewicz A, Sikora E, Pisulewski PM (2007) Effects of some technological processes on GLS contents in cruciferous vegetables. Food Chem 105(3):976-981

16. Rinaldi M, Dall'Asta C, Meli F, Morini E, Pellegrini N, Gatti M, Chiavaro E (2013) Physicochemical and microbiological quality of Sous-Vide-processed carrots and brussels sprouts. Food Bioprocess Tech 6(11):3076-3087

17. PN-90/A-75101/03. Fruit and vegetable products-preparation of samples and testing methods-determination of dry matter content by gravimetric method

18. Commission of the European Communities (1990) Commission Regulation (EC) No 1864/90 of 29 June 1990 amending Regulation (EEC) No 147/68 on the drawing and reduction of samples and on methods of analysis in respect of oil seed. Brussels 170:27-34

19. Heaney RK, Spinks EA, Hanley AB, Fenwick GR (1986) Analysis of GLS in Rapeseed. Technical bulletin. Agricultural and Food Research Council. Food Research Institute, Norwich, pp 1-25t;/bib>

20. PN-EN ISO 4833-1:2013-12E. Microbiology of the food chainHorizontal method for the enumeration of microorganisms-Part 1: Colony count at 30 degrees $\mathrm{C}$ by the pour plate technique (ISO 4833-1:2013)

21. PN-ISO 4832 2007. Microbiology of food and animal feeding stuffs-Horizontal method for the enumeration of coliformsColony-count technique

22. PN-EN ISO 11290-2/2000. Microbiology of food and animal feeding stuffs-Horizontal method for the detection and enumeration of Listeria monocytogenes-Part 2: Enumeration method (ISO 11290-2:1998)

23. PN-ISO 15213:2005P. Microbiology of food and animal feeding stuffs-Horizontal method for the enumeration of sulfite-reducing bacteria growing under anaerobic conditions

24. Ahmed FA, Ali RFM (2013) Bioactive compounds and antioxidant activity of fresh and processed white Cauliflower. BioMed Res Int. doi:10.1155/2013/367819 
25. Gębczyński P, Lisiewska Z (2006) Comparison of the level of selected antioxidative compounds in frozen broccoli produced using traditional and modified methods. IFSET 7:239-245

26. Mansour AA, Elshimy NM, Shekib LA, Sharara MS (2015) Effect of domestic processing methods on the chemical composition and organoleptic properties of Broccoli and Cauliflower. AJFN 3(5):125-130

27. Podsędek A, Sosnowska D, Anders B (2010) The effect of cooking condition on hydrophilic antioxidants in Brussels sprouts. Funct Plant Sci Biotechnol 4(1):97-101

28. Ciska E, Drabińska N, Honke J, Narwojsz A (2015) Boiled Brussels sprouts: a rich source of GLS and the corresponding nitriles. J Funct Foods 19(part A):91-99

29. Carlson DG, Daxenbichler ME, van Etten CH (1987) GLS in Crucifer Vegetables: Broccoli, Brussels Sprouts, Cauliflower, Collards, Kale, Mustard Greens, and Kohlrabi. JASHS 112(1):173-178

30. Brown AB, Yousef GG, Jeffery EH, Klein BK, Wallig MA, Kushad MM, Mosbah JAJ, Kushad M, Juvik JA (2002) GLS profiles in Broccoli: variation in levels and implications in breeding for cancer chemoprotection. JASHS 127(5):807-813

31. Delonga K, Radojčić I, Dragović-Uzelac V, Mrkić V, VorkapićFurač J (2007) Distribution of GLS in some raw and processed Brassica vegetables grown in Croatia. Acta Aliment 36(2):207-216

32. Mithen RF, Dekker M, Verkerk R, Rabot S, Johnson IT (2000) The nutritional significance, biosynthesis and bioavailability of GLS in human foods. J Sci Food Agric 80(7):967-984

33. Bones AM, Rossiter JT (2006) The enzymic and chemically induced decomposition of GLS. Phytochem 67(11):1053-1067
34. Sarvan I, Verkerk R, van Boekel M, Dekker M (2014) Comparison of the degradation and leaching kinetics of GLS during processing of four Brassicaceae (broccoli, red cabbage, white cabbage, Brussels sprouts). IFSET 25:58-66

35. Rungapamestry V, Duncan AJ, Fuller Z, Ratcliffe B (2006) Changes in GLS concentrations, myrosinase activity, and production of metabolites of GLS in cabbage (Brassica oleracea var. capitata) cooked for different durations. J Agric Food Chem 54(20):7628-7634

36. Verkerk R, Dekker M (2004) GLS and myrosinase activity in red cabbage (Brassica oleracea L. var. Capitata f. rubra DC.) after various microwave treatments. J Agric Food Chem 52(24):7318-7323

37. Vallejo F, Tomas-Barberan FA, Garcia-Viguera C (2002) GLS and vitamin $\mathrm{C}$ content in edible parts of broccoli florets after domestic cooking. Eur Food Res Technol 215(4):310-316

38. Miglio C, Chiavaro E, Visconti A, Fogliano V, Pellegrini N (2008) Effects of different cooking methods on nutritional and physicochemical characteristics of selected vegetables. J Agric Food Chem 56(1):139-147

39. Hanschen FS, Lamy E, Schreiner M, Rohn S (2014) Reactivity and stability of GLS and their breakdown products in foods. Angew Chem Int Edit 53:11430-11450

40. Verkerk R (2002) Evaluation of GLS levels throughout the production chain of Brassica vegetables; Towards a novel predictive modelling approach. $\mathrm{PhD}$ dissertation. Wageningen University, Wageningen

41. Sarvan I, Verkerk R, Dekker M (2012) Modelling the fate of GLS during thermal processing of Brassica vegetables. LWTFood SciTechnol 49:178-183 